DOERMOTC-020169

\title{
Weatherford Inclined Wellbore Construction
}

Final Report for the Period May 9, 2002 - May 31, 2002

Date Published: August 19, 2002

R. Schulte

\section{PREPARED FOR THE UNITED STATES DEPARTMENT OF ENERGY/ROCKY MOUNTAIN OILFIELD TESTING CENTER}

Work Performed Under Rocky Mountain Oilfield Testing Center (RMOTC)

CRADA No. 2002-016

Distribution A - Approved for public release; further dissemination unlimited (Unclassified) 


\section{Disclaimer}

This report was prepared as an account of work sponsored by an agency of the United States Government. Neither the U. S. Government nor any agency thereof, nor any of their employees, make any warranty, expressed or implied, nor assumes any legal liability or responsibility for the accuracy, completeness, or usefulness of any information, apparatus, product, or process disclosed, or represents that its use would not infringe privately owned rights. Reference herein to any specific commercial product, process, or service by trade name, trademark, manufacturer, or otherwise does not necessarily constitute or imply its endorsement, recommendation, or favoring by the United States Government or any agency thereof. The views and opinions of authors expressed herein do not necessarily state or reflect those of the United States Government or any agency thereof. 


\begin{abstract}
The Rocky Mountain Oilfield Testing Center (RMOTC) has recently completed construction of an inclined wellbore with seven (7) inch, twenty-three (23) pound casing at a total depth of 1296 feet. The inclined wellbore is near vertical to 180 feet with a build angle of approximately $4.5^{\circ}$ per hundred feet thereafter. See Figure 1 . The inclined wellbore was utilized for further proprietary testing after construction and validation. The wellbore is available to other companies requiring a cased hole environment with known deviation out to fifty degrees $\left(50^{\circ}\right)$ from vertical. The wellbore may also be used by RMOTC for further deepening into the fractured shales of the Steele and Niobrara formation.
\end{abstract}

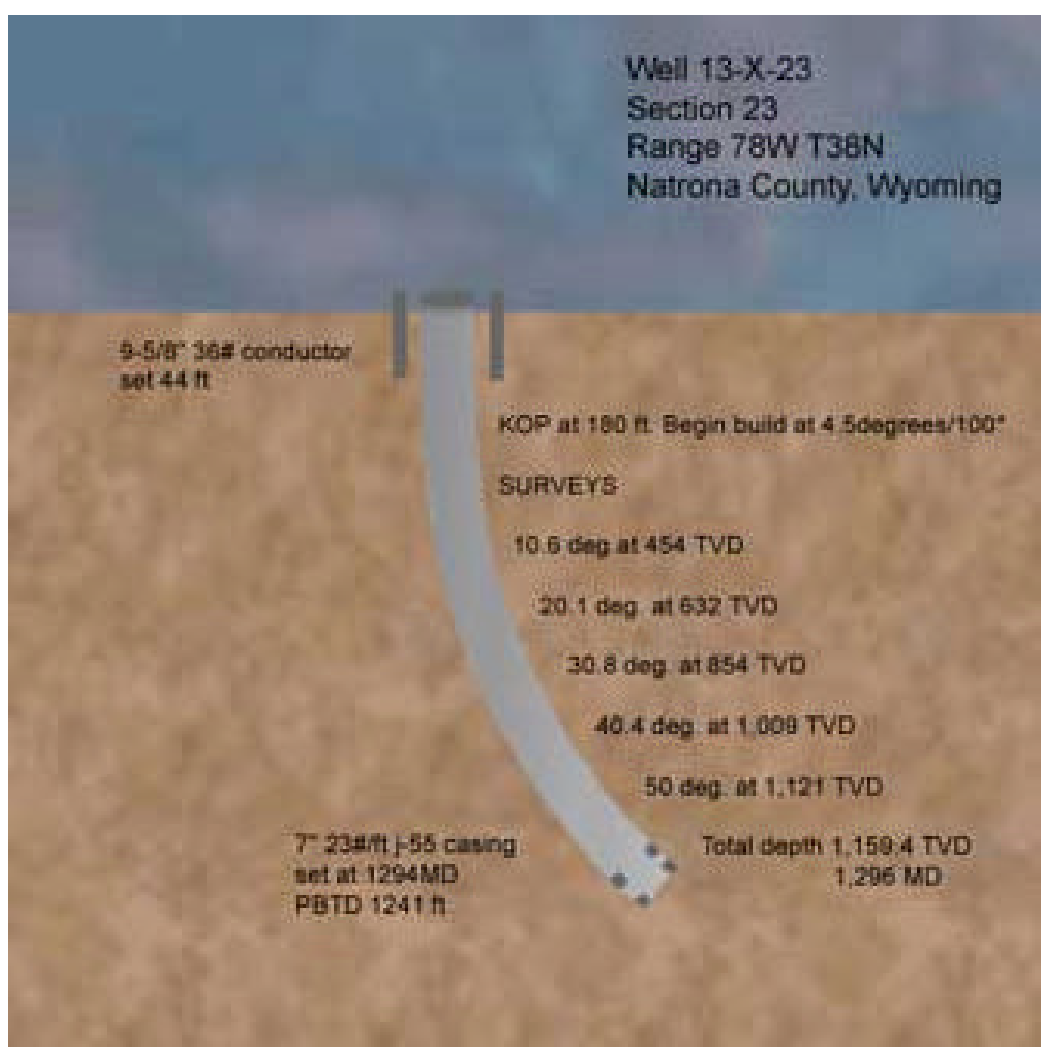

Figure 1. 


\section{Introduction}

The Rocky Mountain Oilfield Testing Center (RMOTC) has recently completed a grass roots drilling of a slant wellbore at the Teapot Dome oil field, also known as the Naval Petroleum Reserve No. 3 (NPR-3), located thirty-five (35) miles north of Casper, Wyoming (See Figure 2). RMOTC together with industry partner, Weatherford, began planning for the wellbore in April, 2002. Drilling was completed in May, 2002, along with the follow-up cased hole work. During the testing process RMOTC provided a complete drilling rig with crews, a newly built location, and a workover rig, as well as circulating equipment and tubing to complete the tests.

\section{Background}

\section{Existing Wellbores}

During April, 2002, RMOTC was contacted by Weatherford regarding a test that would involve an inclined wellbore. During the last twenty-five (25) years of development, several slant holes have been drilled at the Naval Petroleum Reserve 3. The majority of these wellbores were drilled as an attempt to exploit the fractured marine shales of the Steele and Niobrara formations present at Teapot Dome. See Figure 2 for field location.

The slant hole design of these historical wells was to intercept the natural fracture present in the shale formations. Some of the wells were drilled at a twenty (20) degree angle from surface utilizing a slant hole rig obtained from the Nevada test site.

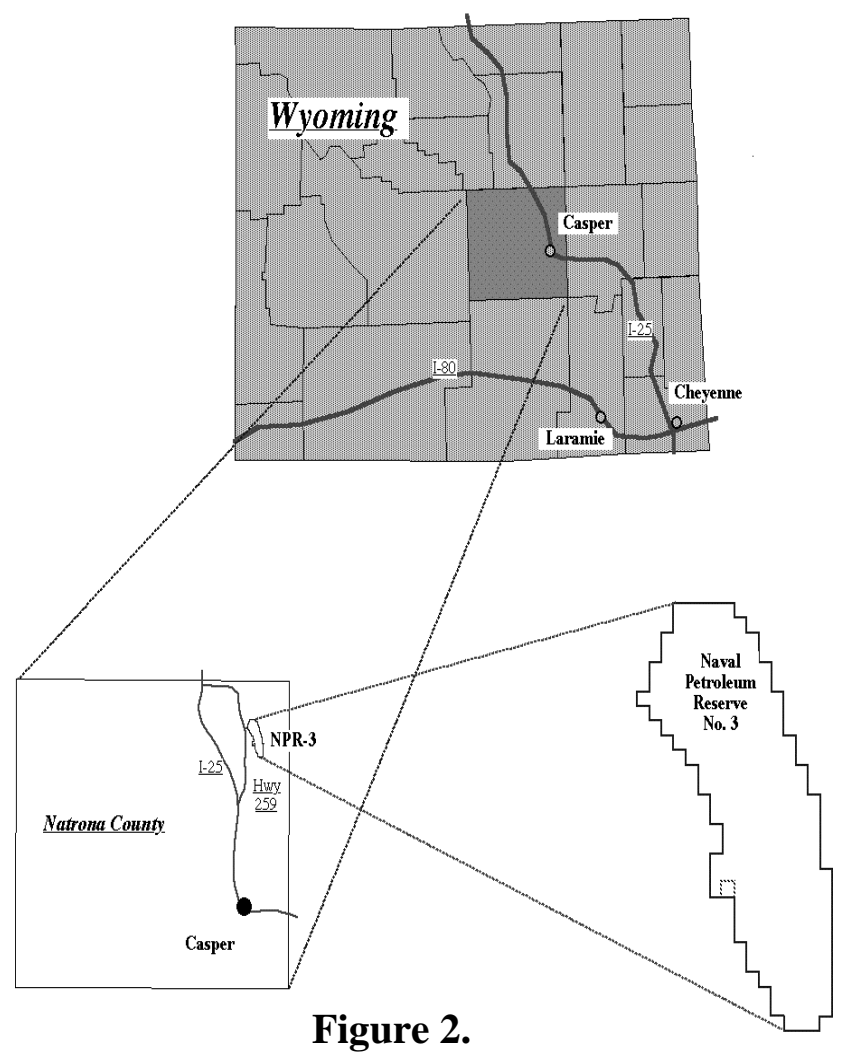

The preliminary screening of possible candidate wells indicated that a new wellbore would have to be drilled based on the technical requirements of the project. Casing size for the proposed testing was limited to seven (7) inch, twenty-three (23) pound casing which eliminated the majority of the wellbores. An additional project requirement was for essentially $100 \%$ bond through the cased section with only one string of casing present. Another well consideration favored a wellbore with a vertical section and then deviated out to fifty degrees $\left(50^{\circ}\right)$ from vertical. The combination of these parameters resulted in an early decision to drill and case an entirely new well at RMOTC. 
The process of determining the location of the proposed well involved consideration of depth intervals; analysis of fracture systems related to the shales; production considerations of existing shale wells; structural constraints; and topographic considerations for surface work related to the cased hole testing. The location selected, $13-\mathrm{X}-23$, is located in the southern end of the field where the immediate surface topography is gradual. See Figure 3.

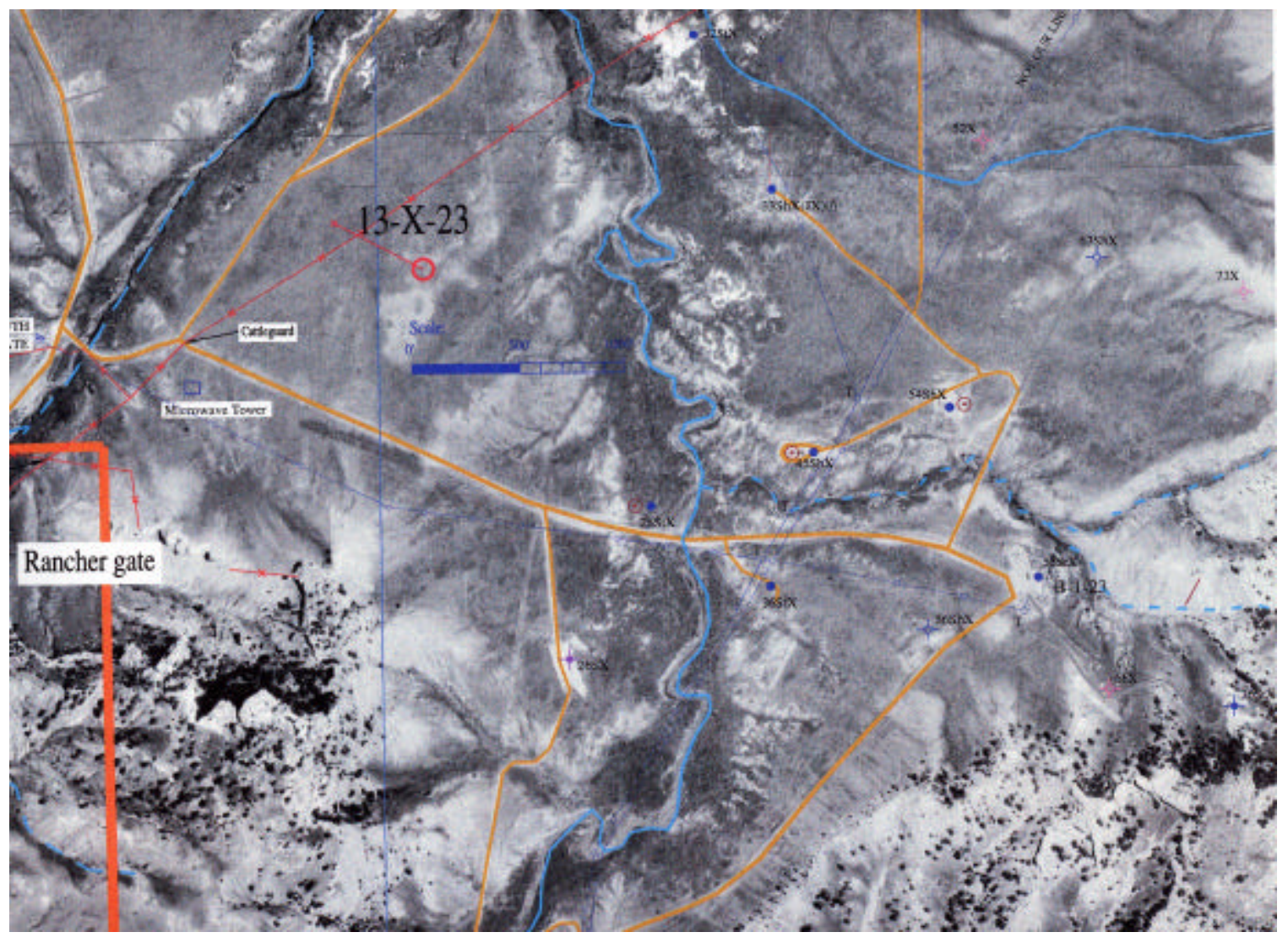

Figure 3 .

\section{Selection of Location}

The 13-X-23 location was selected based on several objectives. The primary objective was to ensure an adequate cased wellbore for further seismic testing. Specific parameters were provided by the client in regards to their cased hole testing requirements which are discussed in more detail further in this report. In addition to fulfilling the client testing requirements, RMOTC desired to maximize future use of the wellbore. Future use included deepening the well at some future date to the fractured shale zones of the Steele and Niobrara formation. Other anticipated uses included future RMOTC clients needing a cased wellbore inclined from vertical to fifty degrees $\left(50^{\circ}\right)$ from vertical. 


\section{Casing Design}

The casing had to be seven inch (7) twenty-three (23) pounds per foot throughout the test section. The tools tested in the cased hole were specifically designed for this size casing and weight. Shallow wells were unavailable to meet this requirement as RMOTC generally uses this weight of casing only in the deeper Tensleep formation ( 5500 feet). No wells existed at the proposed deviation. Fortunately, RMOTC had recently purchased casing of the necessary weight and grade as part of the Active Drilling Program and was available to be used in the project preventing any undue delay in implementing the project.

\section{Depth Limitations}

The depth limitation was determined primarily by the geometry of the proposed wellbore - vertical section on top with a build of $4.5^{\circ}$ per hundred and a final deviation from vertical of fifty degrees $\left(50^{\circ}\right)$. See Figure 4 . Based on these physical limitations, the minimum depth limitation from surface was estimated at approximately 1200 feet true vertical depth (TVD). This estimate was based on a kickoff point at 200 feet subsurface.

The depth specification of 1200 feet limited the location of the well to the edges of Teapot Dome based on the following considerations. The shallowest producing formation at Teapot Dome is the Shannon sandstone consisting of two (2) benches. The Shannon, at the top of the structure, is approximately 300 feet below surface. The geology of the Shannon and the associated EOR projects have been discussed extensively elsewhere. ${ }^{1 ; 2}$

Along the edges of the field the Shannon, is approximately 1000 feet in depth preventing a horizontal lateral from being developed based on the physical constraints of this project. One of the initial concepts was to actually drill a horizontal lateral in the Shannon for RMOTC's further use and production. Based on the geometry of the well, the decision was made to place the test well in a portion of the field where the underlying fractured shales might be developed with a deepening of the wellbore some time in RMOTC's future. Although considered for development, the Shannon reservoir was found to be too shallow based on the physical constraints of the project.

Vertical Section (FT)@ 291.75 deg 0 $\quad 50 \quad 100150 \quad 200250300 \quad 350400450500$

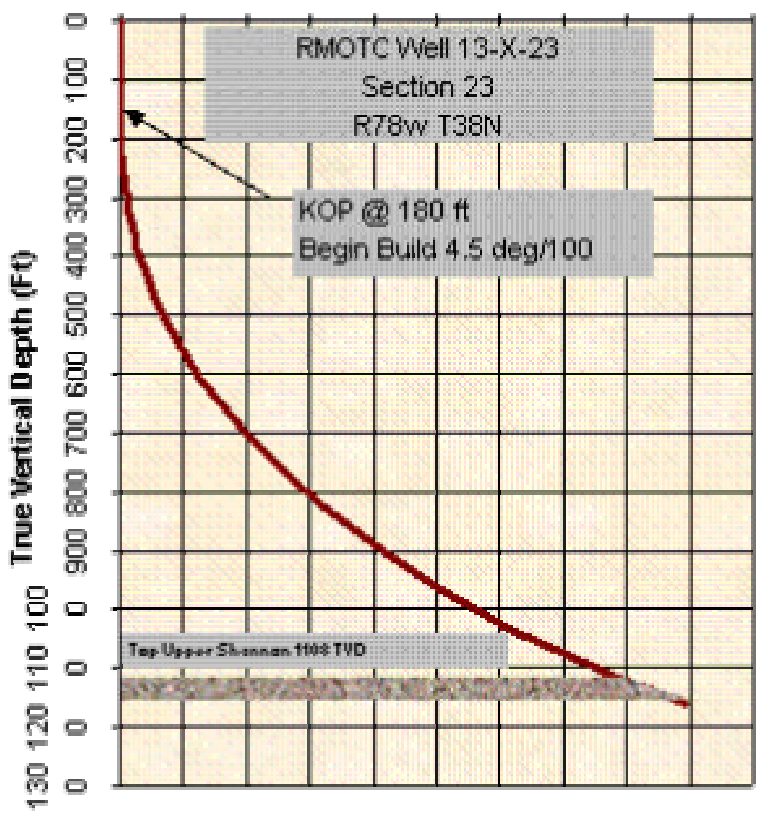

Figure 4. 


\section{Cement Bond Limitations}

Based on the requirement of a wellbore with essentially 100 percent bond throughout further defined the total depth of the well to the Shannon interval or above. Below the Shannon interval, exists the natural fractured shale interval of the Steele and Niobrara shale at Teapot Dome field. The possibility of poor cement bonds exist in these intervals due to encountering open fractures which can limit complete circulation of cement to surface and/or loss of cement to the fractures after the cement job is pumped. The circulation of cement to surface during a primary cementing job has not historically been a significant problem when developing Shannon producers/injectors of which over five hundred (500) wells have been drilled and completed.

\section{Orientation of Wellbore}

After the initial depth limitation was analyzed, the decision was made to drill a well along the edges of the field where the Shannon is of adequate depth to achieve the desired inclination angle assuming a build angle of $4.5^{\circ}$ per hundred feet. Due to the possibility of further development of the fractured shales below the Shannon the eastside of the field, with offset owners beyond the property line, was eliminated to reduce possible delays in permitting due to the offset royalty owners' involvement. The southern end of the field was chosen based on depth requirements and distance from reserve boundaries.

\section{Production Considerations}

The Steele and Niobrara have been significant production zones at Teapot Dome since the early 1920's when several of the early well blowouts occurred while drilling through the fractured shale intervals. To date the Steele Shale reservoir at Teapot Dome has produced 2.04 million barrels of oil (MMBO) and the Niobrara Shale has produced 1.15 million barrels of oil (MMBO).

The most prolific Steele producer has been Well 55-STX-23 (Section 23, T38N, R78W) of the Naval Petroleum Reserve 3. Well 55-STX-23 has produced over 340,000 barrels of oil and accounting for approximately 16 percent of the entire production from the formation. Thus far there have been approximately 128 producers completed in the Steele Shale. 


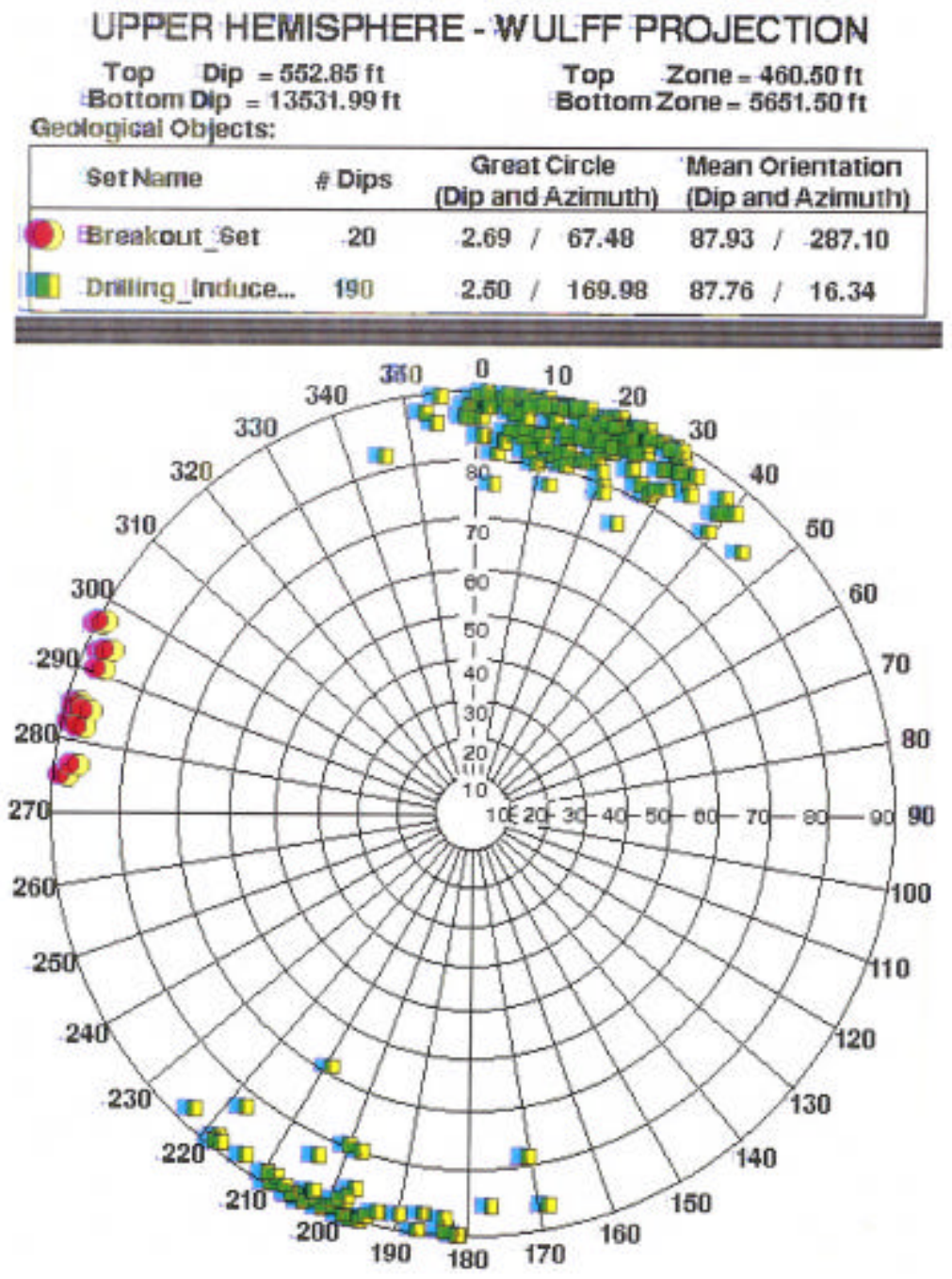

The largest production bubble corresponds to Well 55-STX-23 at the southern end of the field in section 23. This well is also unique in several other respects. It is one of the few shale wells at Teapot Dome that has been cased and then perforated and fracture stimulated. The majority of the wells are completed openhole to allow the fractures to bleed into the wellbore. The exact orientation of the fracture treatment was largely unknown until recent data (2002) indicated a likely fracture orientation.

Figure 5.

\section{Induced Fracture Orientation of 67-X-10}

RMOTC has recently completed the drilling of a new Tensleep well (67-TPX-10) at a distance of 1.5 miles north of 13-X-23. In addition to the normal logging suite used in the field, Schlumberger's formation imaging tool (FMI) was ran over the entire wellbore interval. Figures 5 and 6 are the processed data representation indicating the present day stress orientation due to the presence of drilling induced fractures identified within the openhole wellbore.

The drilling induced are striking WNW/ESE. The drilling fractures propagate towards the orientation of maximum principle stress and "wedge open" against the minimum. Schlumberger states, "Drilling induced tensile fractures are identical in orientation to future hydraulic stimulation." 


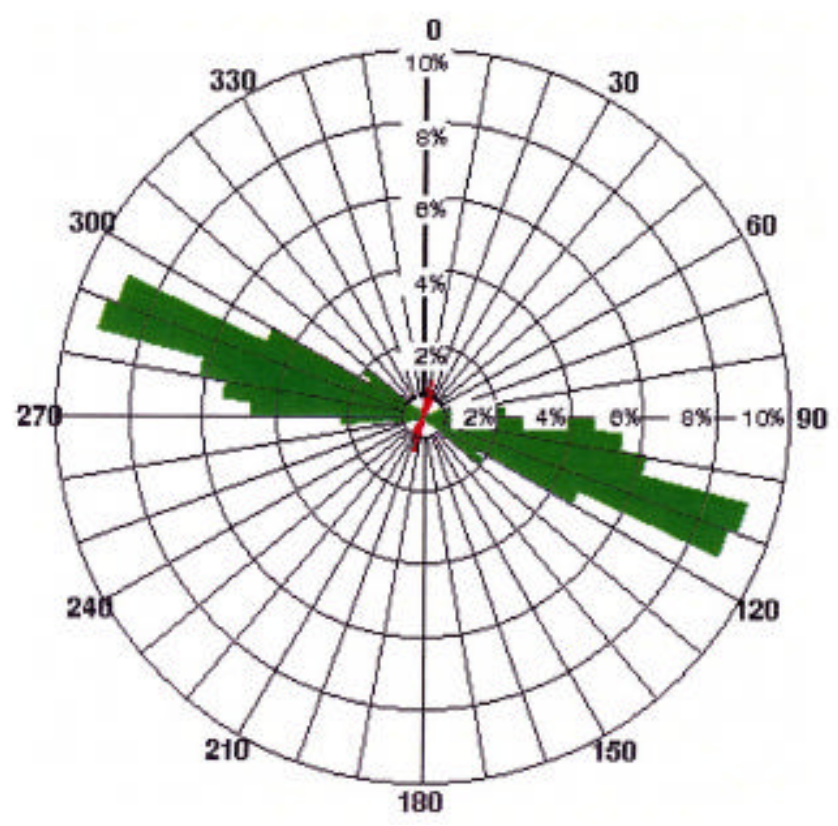

The orientation of the hydraulic fracture stimulation treatments, based on the above data, would be in the WNW/ESE oriention at approximately $290^{\circ}\left(0^{\circ}-\right.$ being north). This orientation is further validated by older injection/production data in the EOR pilots performed in the Shannon reservoir at shallow depths. See Figure 7 and References 1 and 2. Steam injection and subsequent temperature, oil and water response were often observed in the same WNW/ESE orientation at approximately $280^{\circ}$.

Figure 6.

The EOR pilots also had other response directions but the WNW/ESE direction was a dominant observation. Based on this direction the last pattern developed in the steamdrive was a line drive with two parallel lines of injectors - Generator 5A pattern.

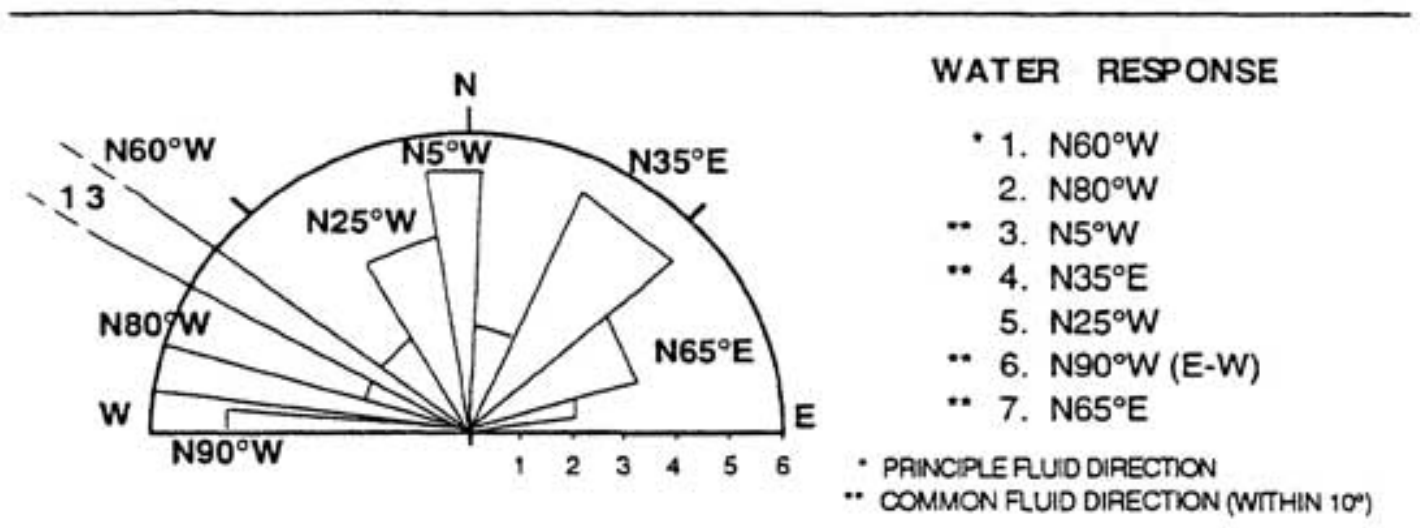

FIGURE 15. Rose diagram of priocipal direction and magaitude of water production (WOR $>80 \%$ ) is $<3$ montas.

Figure 7. 
The orientation of $290^{\circ}$ for the inclined portion of the $13-\mathrm{X}-23$ wellbore was selected based on the above considerations. In summary, Well 55-STX-23 has been an excellent producer in the fractured shales. The propped hydraulic stimulation of Well 55-STX-23 propagated in the WNW/ESE direction based on openhole logging of 67-X-10 and previous injection/production trends of the EOR pilots. If Well 13-X-23 is deepened in the future to the Shales then the openhole portion of the well will be analogous to the propped fracture of 55-STX-23.

Well 13-X-23 was also placed on the western flank of the anticline. The future openhole portion will be located in Section 22 which has been only lightly explored. Figure 8 is a cumulative oil bubble map showing the tremendous recovery of well 55-STX23 which is located on the eastern flank of the anticline. It is probable that the well drained a large portion of the Steele formation, either by gravity or solution gas drive, on the eastern flank. The amount of depletion of the western flank, if fractures are

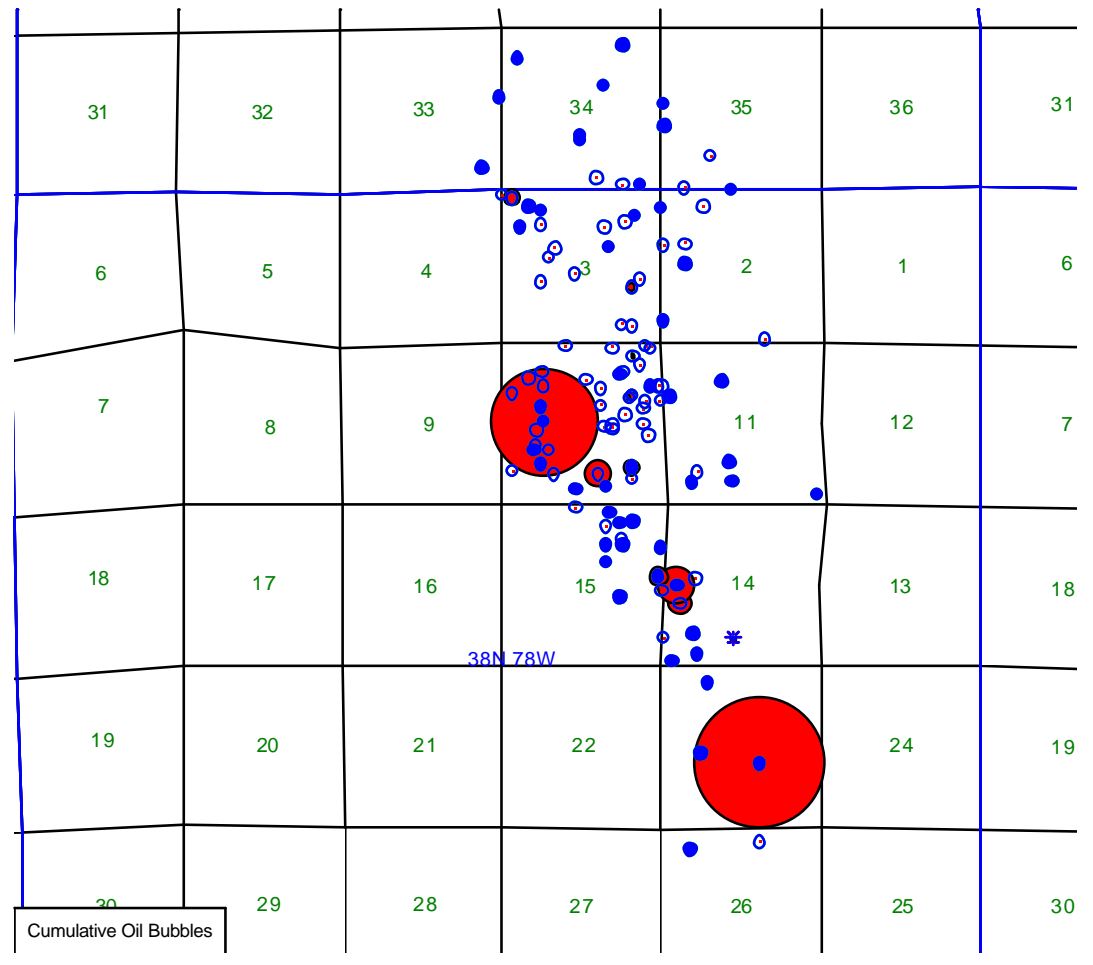
present, should be less with more possible recovery.

Figure 8.

\section{Drilling Summary}

In general, the drilling of Well $13-\mathrm{X}-23$ proceeded relatively quickly. Appendix A is a summary of the surveys. A $1.5^{\circ}$ bent motor was used to build the required angle at depth. The initial build angle was slightly lower than planned but final build rate was slightly higher than planned. The net effect being a wellbore going from near vertical at 180 feet to $50.5^{\circ}$ at 1296 feet measured depth.

During drilling, Weatherford Drilling and Intervention Services recorded an openhole gamma ray and associated inclination and azimuth information. The top of the Upper Shannon is estimated at 1033 TVD and the Lower Shannon is at 1106 feet TVD. Based on the openhole gamma ray drilling was terminated after meeting the pre-defined objective of casing through the Shannon at the appropriated inclination. 


\section{Logging Suite}

Upon completion of drilling, openhole logs were run by Halliburton services. The logs included a four (4) arm caliper for cement volume calculations, a conventional density porosity $\log$ and an extensive suite of acoustic $\operatorname{logs}$ to characterize the formation.

The caliper plot indicated a fairly consistent hole size with just a few enlargements. The density $\log$ indicated a porosity of 14 to17 percent for the Upper Shannon bench and 17 to 21 percent for the Lower Shannon bench. This porosity range is reversed from what is normally found in the productive areas of the field. The Upper Shannon typically has a higher porosity and permeability than the Lower Shannon. At the southern end of the field, the Shannon is below the oil bearing rock and is not productive.

\section{Cement Design}

The cement design utilized Halliburton's Super CBL expand ing cement with a calculated 25 percent excess based on the four (4) arm caliper log. The initial design was for 14.2 ppg cement. The initial attempt was to batch mix the cement at surface to achieve the desired weight and then pump the cement downhole. Unfortunately, the field experience found that the cement overflowed the batch mixer and the entire batch was discarded. The next attempt was to mix the cement on-the-fly which worked quite well with adequate weight control.

\section{Centralizer Design}

To ensure the best possible bond in the inclined wellbore both between the pipe and cement as well as the cement and the openhole, sixty-one (61) centralizers were placed along the length of the casing from 1294 feet measured depth to surface or approximately two (2) centralizers per joint of pipe.

\section{Bit Usage}

The Cretaceous age formations that the Shannon is a member are usually fairly soft and quite drillable with either air or water based muds. The bit selected for drilling was a Hughes GTS-09. Penetration rates were approximately forty-one (41) feet/hr with a combination of sliding and rotating to minimize hole ledges or dog-legs. 


\section{WellBore Validation}

At the end of drilling, logging and cementing, the RMOTC drilling rig was moved off location. RMOTC then moved in a workover rig to complete the validation of the wellbore for further use.

The validation consisted of a two step process. The first step was to run a bit and casing scaper from surface to plug back total depth (PBTD). The objective was to confirm that cased hole tools could be safely run without concern for loss. The second step was the running of a cased hole bond log to ensure adequate bond was present throughout the interval.

The bond log run by Halliburton showed very good bond throughout the entire build section. The bond was poorer from approximately surface to 290 feet measured depth. At this depth the deviation from vertical is approximately four degrees $\left(4^{\circ}\right)$. The impact of the poorer bond above 290 feet, although not desirable, was considered to be acceptable by Weatherford. The net result was a validated wellbore accepted by the client for further cased hole seismic work.

\section{Summary}

RMOTC and its industry partner, Weatherford, were able to plan, permit, drill and complete an inclined wellbore in a span of less than two (2) months from start to finish. The cased hole wellbore is now available for further testing by RMOTC partners. Drilling proceeded fairly quickly with only minor difficulties. Planned versus actual build rates were very acceptable. The cement bond showed excellent results throughout the majority of the build section. Cementing operations were modified based on the overflow of the batch mixer on the first attempt. The cement was mixed on the fly for the second attempt which was successful. The wellbore was validated and accepted by the client after a casing scraper was run and a cased hole bond log was completed. 


\section{Footnotes}

1. $\quad$ Olsen, D.K., P.S. Sarathi, M.L. Hendricks, R.K. Schulte and L.A. Giangiacomo: "Case History of Steam Injection Operations at Naval Petroleum Reserve No.3, Teapot Dome Oil Field, Wyoming: A Shallow Heterogeneous Light-Oil Reservoir," SPE 25786, presented at the 1993 SPE International Thermal Operations Symposium, Bakersfield, CA, February 8-10, 1993.

2. Doll, T.E., D.K. Luers, G.R. Strong, R.K.Schulte, P.S. Sarathi and D.K. Olsen: ” An Update of Steam Injection Operations at Naval Petroleum Reserve No. 3, Teapot Dome Oil Field, Wyoming: A Shallow Heterogeneous Light Oil Reservoir," SPE 30286, presented at the International Heavy Oil Symposium, Calgary, Alberta, Canada, June 19-21, 1995. 
Appendix A

Survey Results 


\begin{tabular}{|c|c|c|c|c|c|c|c|c|c|}
\hline \multicolumn{10}{|c|}{$\begin{array}{c}\text { Well 13-X-23 Survey Calculations } \\
\text { Survey Company: Weatherford Dailey Directional } \\
\text { Surface Location: } 2,017 \mathrm{ft} \mathrm{FNL} \mathrm{\&} 248 \mathrm{ft} \text { FWL Section } 23 \\
\text { Range 78 West Township 38N } \\
\text { Natrona County. Wyoming } \\
\text { Bottomhole Location: } 1,809.79^{\prime} \text { FNL \& } 271.38^{\prime} \text { FEL Sec } 22 \\
\text { Minimum Curvature Method } \\
\text { Vertical Section Plane } 291.75 \\
\text { Vertical Section Referenced to offset from Wellhead: EW }=.00 \mathrm{ft}, \mathrm{NS}=.00 \mathrm{ft}\end{array}$} \\
\hline \multirow[b]{2}{*}{$\begin{array}{c}\text { Measured } \\
\text { Depth FT }\end{array}$} & \multirow[b]{2}{*}{$\begin{array}{c}\text { Incl Angle } \\
\text { Deg }\end{array}$} & \multirow[b]{2}{*}{\begin{tabular}{|c|} 
Drift \\
Direction \\
DEG
\end{tabular}} & \multirow[b]{2}{*}{$\begin{array}{l}\text { True } \\
\text { Vertical } \\
\text { Depth }\end{array}$} & \multirow[b]{2}{*}{$\begin{array}{l}\text { N.S } \\
\text { FT }\end{array}$} & \multirow[b]{2}{*}{$\begin{array}{l}\text { E-W } \\
\text { FT }\end{array}$} & \multicolumn{3}{|c|}{ CLOSURE } & \multirow[b]{2}{*}{$\begin{array}{l}\text { Dogleg } \\
\text { Sewerity } \\
\text { Deg/100 }\end{array}$} \\
\hline & & & & & & $\begin{array}{l}\text { Vertical } \\
\text { Section FT }\end{array}$ & $\begin{array}{c}\text { Distance } \\
\text { FT }\end{array}$ & \begin{tabular}{|c} 
Direction \\
Deg
\end{tabular} & \\
\hline 0.00 & 0.00 & 0.00 & 0.00 & 0.00 & 0.00 & 0.00 & 0.00 & 0.00 & 0.00 \\
\hline 92.00 & 0.10 & 183.20 & 92.00 & -0.08 & 0.00 & -0.03 & 0.08 & 183.19 & 0.11 \\
\hline 122.00 & 0.10 & 23.40 & 122.00 & -0.08 & 0.00 & -0.03 & 0.08 & 176.89 & 0.66 \\
\hline 152.00 & 0.20 & 19.20 & 152.00 & -0.01 & 0.03 & -0.03 & 0.03 & 105.32 & 0.34 \\
\hline 183.00 & 0.80 & 322.10 & 183.00 & 0.21 & -0.08 & 0.16 & 0.23 & 338.70 & 2.30 \\
\hline 213.00 & 1.50 & 301.70 & 212.99 & 0.58 & -0.55 & 0.72 & 0.80 & 36.97 & 2.67 \\
\hline 243.00 & 2.40 & 298.80 & 242.97 & 1.09 & -1.43 & 1.73 & 1.80 & 307.40 & 3.02 \\
\hline 274.00 & 3.30 & 295.90 & 273.94 & 1.80 & -2.80 & 3.27 & 3.33 & 302.66 & 2.94 \\
\hline 305.00 & 4.50 & 298.40 & 304.86 & 2.76 & -4.57 & 5.37 & 5.43 & 300.60 & 3.91 \\
\hline 335.00 & 5.70 & 300.40 & 334.74 & 4.08 & .6 .99 & 8.01 & 8.10 & 300.24 & 4.04 \\
\hline 366.00 & 7.00 & 300.60 & 365,55 & 5.82 & -9.95 & 11.40 & 11.53 & 300.32 & 4.19 \\
\hline 395.00 & 820 & 300.20 & 394.30 & 7.76 & -13.26 & 15.19 & 15.36 & 300.34 & 4.14 \\
\hline 426.00 & 9.40 & 300.80 & 424.93 & 10.17 & -17.34 & 19.88 & 20.10 & 30.38 & 3.88 \\
\hline 456.00 & 10.60 & 301.30 & 454.48 & 12.85 & -21.80 & 25.02 & 25.31 & 300.52 & 4.01 \\
\hline 487.00 & 12.00 & 300.80 & 484.87 & 15.99 & -27.01 & 31.01 & 31.39 & 300.62 & 4.53 \\
\hline 517.00 & 13.40 & 300,00 & 514.14 & 19.32 & -32.70 & 37.53 & 37.98 & 300.58 & 4.70 \\
\hline 547.00 & 15.00 & 298.20 & 543.22 & 22.89 & -39.13 & 44.83 & 45.34 & 300.33 & 5.53 \\
\hline 578.00 & 16.60 & 296.90 & 573.05 & 26.79 & -46.62 & 53.23 & 53.77 & 299.89 & 5.29 \\
\hline 609.00 & 18.30 & 296.30 & 602.62 & 30.95 & -54.93 & 62.49 & 63.05 & 299.40 & 5.51 \\
\hline 640.00 & 20.10 & 295.90 & 631.90 & 35.44 & -64.08 & 72.65 & 73.23 & 298.94 & 5.82 \\
\hline 670.00 & 21.60 & 295.30 & 659.93 & 40.05 & -73.71 & 83.31 & 83.89 & 298.52 & 5.05 \\
\hline 701.00 & 22.60 & 295.20 & 688.65 & 45.02 & -84.26 & 94.95 & 95.54 & 298.12 & 3.23 \\
\hline 730.00 & 23.70 & 295.20 & 715.32 & 49.88 & -94.58 & 106.33 & 106.93 & 297.81 & 3.79 \\
\hline 760.00 & 25.20 & 294.60 & 742.63 & 55.10 & -105.84 & 118.73 & 119.33 & 29750 & 5.07 \\
\hline 791.00 & 26.60 & 293.40 & 770.51 & 60.61 & -118.21 & 132.26 & 132.84 & 297.14 & 4.82 \\
\hline 823.00 & 27.90 & 292.80 & 798.96 & 66.36 & -131.69 & 146.90 & 147.46 & 296.74 & 4.15 \\
\hline 855.00 & 29.30 & 292.30 & 827.06 & 72.23 & -145.84 & 162.22 & 162.74 & 296.35 & 4.44 \\
\hline 886.00 & 30.80 & 292.10 & 853.89 & 78.09 & -160.21 & 177.74 & 178.23 & 295.99 & 4.85 \\
\hline 918.00 & 32.20 & 292.00 & 881.17 & 84.37 & -175.71 & 194.46 & 194.91 & 295.65 & 4.38 \\
\hline 949,00 & 33.50 & 291.40 & 907.21 & 90.59 & -191.33 & 21128 & 211.69 & 295.34 & 4.32 \\
\hline 981.00 & 34.90 & 290.70 & 933.68 & 97.04 & -208.12 & 2229.26 & 229.63 & 29500 & 4.54 \\
\hline 1013.00 & 36.90 & 290.30 & 959.60 & 103.61 & .225 .69 & 248.02 & 248.34 & 294.86 & 6.29 \\
\hline 1045,00 & 38.70 & 289.90 & 984.88 & 110.35 & -244.11 & 287.62 & 267.89 & 294.33 & 5.68 \\
\hline 1076.00 & 40.40 & 289.90 & 1008.79 & 117.07 & -262.67 & 287.35 & 28758 & 294.02 & 5.48 \\
\hline 1107.00 & 42.10 & 289.90 & 1032.09 & 124.03 & -281.89 & 307.78 & 307.97 & 293.75 & 5.48 \\
\hline 1140.00 & 44.20 & 289.90 & 1056.17 & 131.71 & -303.11 & 330.34 & 330.49 & 293.49 & 6.36 \\
\hline 1171.00 & 46.40 & 289.50 & 1077.97 & 139.13 & -323.85 & 352.36 & 352.48 & 293.25 & 7.16 \\
\hline 1203.00 & 48.40 & 289.70 & 1098.63 & 147.04 & -346.04 & 375.89 & 375.99 & 293.02 & 6.27 \\
\hline 1235.00 & 50.00 & 290.00 & 1120.54 & 155.26 & -368.83 & 400.10 & 400.17 & 292.83 & 5.05 \\
\hline 1249.00 & 50.50 & 289.90 & 1129.49 & 158.93 & .378 .94 & 410.86 & 410.92 & 292.75 & 3.61 \\
\hline 1296.00 & 50.50 & 289.90 & 1159.39 & 171.28 & -413.04 & 447.11 & 447.15 & 292.52 & \\
\hline
\end{tabular}

